\title{
Communication
}

[Comunicação]

\section{Muscoid Diptera and their parasitoids collected from fish bait in Itumbiara, Goiás}

[Dípteros muscóides e seus parasitóides coletados em isca de peixe em Itumbiara]

\section{C.H. Marchiori, O.M. Silva Filho}

Departamento de Biologia - Instituto Luterano de Ensino Superior de Itumbiara-ILES-ULBRA

Caixa Postal 23-T

75500-000 - Itumbiara, GO

Diptera is one of the largest orders of insects, with abundant numbers of species as well as of individuals. Moreover, dipterous insects have medical and veterinarian importance since they may produce myiasis and may be vectors for microorganisms that are pathogenic to men and animals (Chow, 1940; Greenberg, 1971; D’Almeida, 1984; D’Almeida, 1986).

A diverse fauna of parasitoids exists alongside dipterous insects and is responsible for their natural control. Since parasitoids occupy a superior trophic level, they act as determining factors on the population densities of their hosts, due to the diversity of their physiological and behavioral adaptations. For fly controll natural regulators such as the parasitoids, that are the agents responsible for the reduction of the synanthropic fly population, could be used (Mendes and Linhares, 1993).

This study aimed to estimate the association between parasitoid species and synanthropic Diptera collected from fish bait in traps.

Flies were attracted to traps constructed using dark-colored cans with a matt finish, measuring $19 \times 9 \mathrm{~cm}$. These had two openings of slat type located on the lower third of the cans, to allow flies to enter. Nylon funnels were attached to the tops of the cans, with their narrow bases pointing downwards into the cans. The upper, wide ends of the funnels were open and had plastic bags wrapped around them. The flies were collected by removing these plastic bags. Raw fish was used as bait inside the cans, over a layer of sand. Five traps were hung from eucalyptus trees 1 meter from the ground, 2 meters apart from each other, at a distance of 50 meters from domestic garbage cans. The insects collected were taken to the laboratory, killed using ethyl ether and kept in $70 \%$ ethanol for further identification. The contents of the traps were placed in plastic containers with a layer of sand as a substrate for pupation. The sand was sifted after 15 days and pupae were extracted and placed individually in gelatin capsules (number 00) to obtain the flies and/or parasitoids.

The preference of species for the time of fish exposure was tested by chi-squared test, at $5 \%$ probability.

From March 2001 to April 2002, 140 pupae of Diptera and 43 specimens of parasitoid were collected. The overall percentage of parasitism was $21.4 \%(30 / 140)$. The high prevalence of parasitism can also be related to the ensembles of gregarious parasitoids.

Among the Diptera, Peckia chrysostoma (Wiedemann) (Diptera: Sarcophagidae) was the most abundant, comprising $60.7 \%$ (Tab. 1). Peckia chrysostoma is a widespread neotropical synanthropic species. As shown in Rio de Janeiro, the species had preference for locals inhabited by man, and the bait that most attracts them was raw fish (D'Almeida, 1984). 
Pachycrepoideus vindemmiae (Rondani) (Pteromalidae) was the most frequent species $(60.5 \%)$ followed by Nasonia vitripennis (Walker) (Pteromalidae) corresponding to $37.2 \%$ of the collected parasitoids (Table 1). Pachycrepoideus vindemmiae is a solitary species that affects a great number of Diptera of the families Anthomyiidae, Calliphoridae, Muscidae, Tachinidae and Tephritidae (Gauld and Bolton, 1988). This species presents a widespread (cosmopolitan) distribution and has been found in North America and Africa (Rueda and Axtell, 1985).

Brachymeria podagrica (Fabricius) (Chalcididae), N. vitripennis and $P$. vindemmiae, presented a frequency of $2.3 \%, 37.2 \%$ and $60.5 \%$, respectively. A great number of individuals were obtained from the host Oxysarcodexia thornax (Wiedemann) (Diptera: Sarcophagidae), totaling 21 (53.8\%) (Table 2).
Table 1. Parasitoids collected from fish bait in Itumbiara, Goiás, from March 2001 to April 2002

\begin{tabular}{lcc}
\hline Taxonomic Group & $\begin{array}{c}\text { Number of } \\
\text { specimens }\end{array}$ & Frequency \\
\hline Diptera: & & \\
$\quad$ Sarcophagidae & 39 & 27.9 \\
$\quad$ Oxysarcodexia thornax & 85 & 60.7 \\
$\quad$ Peckia chrysostoma & 15 & 10.7 \\
$\quad$ Sarcodexia lambens & & \\
$\quad$ Sphaeroceridae & 1 & 0.7 \\
$\quad$ Poecilosomella angullata & 140 & 100.0 \\
Total & & \\
$\quad$ & & \\
Hymenoptera: & & \\
$\quad$ Chalcididae & 1 & 2.3 \\
$\quad$ Brachymeria podagrica & & \\
$\quad$ Pteromalidae & & \\
$\quad$ Nasonia vitripennis & 16 & 37.2 \\
$\quad$ Pachycrepoideus vindemmiae & 26 & 60.5 \\
Total & 43 & 100.0 \\
\hline
\end{tabular}

Table 2. Synanthropic flies and their parasitoids collected from fish bait in Itumbiara, Goiás, from March 2001 to April 2002

\begin{tabular}{lccccc}
\hline Taxonomic Group & Frequency & Species & Frequency & $\begin{array}{c}\text { Number of } \\
\text { Parasitized pupae }\end{array}$ & Percentage \\
\hline Oxysarcodexia thornax & 39 & B. podagrica & 1 & 1 & 2.6 \\
& & P. vindemmiae & 20 & 20 & 51.3 \\
Peckia chrysostoma & 85 & N. vitripennis & 16 & 3 & 3.5 \\
Sarcodexia lambens & & P. vindemmiae & 2 & 2 & 2.4 \\
\hline
\end{tabular}

$P$. vindemmiae showed preference for $O$. thornax and Sarcodexia lambens (Diptera: Sarcophagidae) and $N$. vitripennis for $P$. chrysostoma $\left(\lambda^{2}=35.75 ; \mathrm{DF}: 4 ; \mathrm{P}<0.05\right)$.
Results show the importance of these flies as vectors for disease-causing agents.

Keyword: fly, Insecta, Hymenoptera, biocontrol, urban area

\section{RESUMO}

Determinaram-se as espécies de parasitóides associados às moscas sinantrópicas coletados em iscas de peixe, em Itumbiara, Goiás. As pupas, obtidas pelo método de flutuação, foram individualizadas em cápsulas de gelatina até a emergência das moscas adultas ou de seus parasitóides. A porcentagem total de parasitismo foi $21,4 \%$.

Palavras-chave: mosca, Insecta, Hymenoptera, controle biológico, área urbana 


\section{REFERENCES}

CHOW, C.Y. The common blue bottle fly Chrysomya megacephala as a carrier of pathogenic bacteria in Beijing. Chi. Chin. Med., v.57, p.145-153, 1940.

D'ALMEIDA, J.M. Sinantropia de Sarcophagidae (Diptera) na região metropolitana do Estado do Rio de Janeiro. Arq. Univ. Fed. Rural Rio de Janeiro, v.7, p.101-110, 1984.

D’ALMEIDA, J.M. Substratos utilizados para a criação de dípteros caliptrados em uma área rural do Estado do Rio de Janeiro. Arq. Univ. Fed. Rural Rio de Janeiro, v.9, p.13-22, 1986.

GAULD, I.D.; BOLTON, B. The Hymenoptera.
Oxford: Oxford University, 1988. 331p.

GREENBERG, B. Flies and disease: ecology, classification and biotic association. New Jersey: Princeton University, 1971. 856p.

MENDES, J.; LINHARES, A.X. Atratividade por iscas, sazonalidade e desenvolvimento ovariano em várias espécies de Muscidae (Diptera). Rev. Bras. Entomol., v.37, p.289-297, 1993.

RUEDA, L.M.; AXTELL, R.C. Guide to common species of pupal parasites (Hymenoptera: Pteromalidae) of the house fly and other muscoid flies associated with poultry and livestock manure. Techn. Bull. North Carolina Agric. Res. Serv., n.128, p.1-88, 1985. 